\title{
Development of a Taqman real-time PCR assay for detection of Leifsonia xyli subsp xyli
}

\author{
Carla S. Pelosi ${ }^{1}$, Mirian V. Lourenço ${ }^{1,2}$, Melissa Silva ${ }^{1}$, Alexandre Z. Santos ${ }^{2}$, Suzelei C. França ${ }^{1}$ \& Mozart \\ Marins $^{1}$
}

${ }^{1}$ Universidade de Ribeirão Preto - UNAERP, Unidade de Biotecnologia , 14096-900, Ribeirão Preto, SP, Brazil; ${ }^{2}$ Universidade de Ribeirão Preto - UNAERP, Centro de Tecnologia e Desenvolvimento Agroindustrial, 14096-900, Ribeirão Preto, SP, Brazil

Author for correspondence: Mozart Marins, e-mail: marins@heranza.com.br

\begin{abstract}
Leifsonia xyli subsp xyli (Lxx) is the etiological agent of ratoon-stunting disease (RSD), one of the most important diseases that affects productivity of sugarcane crops. The lack of defined external symptoms in most plants is a challenge for the diagnosis of RSD facilitating its spread in production fields. In this study a Taqman ${ }^{\circledR}$ real-time polymerase chain reaction (qPCR) assay was developed for detection of the bacteria in different tissues of the plants and compared to conventional PCR and nested-PCR assays. The bacterial DNA was amplified by the nested-PCR and qPCR assays, indicating that conventional PCR lacks sufficient sensitivity to be used as a diagnostic tool for RSD. On the other hand, qPCR is more advantageous than nested-PCR for processing large amounts of samples since it does not need post processing steps for visualization of results and the level of bacterial infection can be quantified. Therefore by improving the diagnosis of RSD in field plants, it can be applied to monitor losses caused by the disease, as a tool to monitor the efficacy of sanitation procedures and in the development of new sanitizers for Lxx.
\end{abstract}

Key words: Leifsonia xyli subsp xyli, ratoon-stunting disease, sugarcane.

Sugarcane (Saccharum officinarum) is one the most important crops in countries such as Brazil, India and China, respectively the first, second and third world producers (FAO, 2010). The Brazilian Ministry of Agriculture estimates that the 2018-19 sugarcane harvest will result in 47.34 million tons of sugar and 58.8 billions liters of alcohol, in order to support the internal and external growing demand for biofuels, alcohol, sugar and their derivatives. The country leadership production of these commodities is a result of constant improvements in productivity. A crucial aspect is the control of diseases which negatively impact the yield of this crop. One example is ratoon-stunting disease (RSD), which causes worldwide losses varying from 5 to $30 \%$ depending on the susceptibility of the variety planted (Brumbley et al., 2006). Its etiologic agent is the Gram-positive fastidious bacterium Leifsonia xyli subsp xyli $(\mathrm{Lxx})$, which reproduces in the xylem of the plants (Davis et al., 1980, Gillaspie et al., 1981). Infected plants present thinner and smaller stalks, irregular growth, stunted growth and reduced tillering. Internal symptoms can appear as a reddish-brown coloration of the xylem in the basal nodal region, though they are not easy to be spotted (Tokeshi, 1997). Until now, no insect vector has been identified for the bacteria and associated with infection of the plants which occurs through wounds (Gillaspie et al., 1981). Inter-plant transmission and spread of the bacteria occurs by contact with contaminated blades of equipment used during harvest and cultivation (Brumbley et al., 2006, Gillaspie et al., 1981). In order to avoid the spread of the disease in the production fields, the improvement of diagnostic tests is a constant necessity. The observation of external symptoms is considered unreliable since they can be confused with symptoms of water or nutritional stress (Tokeshi, 1997). The use of phase contrast microscopy, serology and PCR in order to detect the bacteria are considered the most efficient diagnostic tests to identify infected plants (Grisham et al., 2007). Among these, PCR based methods are generally considered the most precise, but the costs involved, time and technical skills required to perform the assays are still an obstacle for their application in routine laboratory tests. An important limiting factor for analysis of large amounts of samples is the extent of labour involved in these methodologies which includes post processing of amplification products by gel electrophoresis. This makes these assays laborious and prone to generation of false results. An alternative to speed up PCR based assays is real-time PCR, a method that eliminates post processing of amplification products; quantifiyng of amplified products can be accomplished by incorporation of fluorescent labels in the reaction. In this study we present a Taqman ${ }^{\circledR}$ realtime polymerase chain reaction (qPCR) based assay for identification of Lxx and evaluate its efficiency for detection of the bacteria in different tissues comparing it with a conventional nested-PCR assay. 
Eighty sugarcane samples were collected from fourteen farms from the region of Ribeirão Preto, Brazil, from October 2010 to April 2011. Samples were collected randomly in areas where the RSD was considered to be present. This was based on the visualization of the potential symptoms of the disease of plants in these areas and by serology tests performed with some of the samples. Samples were cleaned, cut and stored in a cold chamber until DNA extraction. Purified Lxx DNA was used as control in the experiments. The leaves and stalks from each of the samples were used in the experiments. DNA extraction from stalk or central vein of leaves was carried out using the CTAB method (Richards et al., 2001). In summary, around 100-150 $\mathrm{mg}$ of the sample were placed in a $2 \mathrm{~mL}$ tube and mechanically grinded to powder with the aid of a glass rod and liquid nitrogen. One $\mathrm{mL}$ of CTAB buffer [CTAB 2\% (p/v); $\mathrm{NaCl}$ 1,4 M; Tris-HCl 100 mM; pH 8,0; EDTA $20 \mathrm{mM}$; b-mercaptoetanol $0,2 \%(\mathrm{v} / \mathrm{v})]$ were added and the mixture was incubated at $65^{\circ} \mathrm{C}$ for 40 minutes in a waterbath. After cooling of the sample to room temperature, 200 microliters of phenol/ chloroform/ isoamyl alcohol solution (25:24:1) was added, followed by centrifugation for 2 minutes at 17,200 g. The aqueous phase was transferred to a new tube and DNA was precipitated at $-20^{\circ} \mathrm{C}$ for 10 minutes after addition of $600 \mu \mathrm{l}$ of ice-cold isopropanol. The mixture was centrifuged for 5 minutes at $17,200 \mathrm{~g}$ and the supernatant discarded. One $\mathrm{mL}$ of wash buffer (ethanol $70 \%$, ammonium acetate $10 \mathrm{mM}$ ) was added, the pellet was detached from the bottom of the tube and incubated at room temperature for 20 minutes. After 5 minutes centrifugation at $17,200 \mathrm{~g}$ at $4^{\circ} \mathrm{C}$, the supernatant was discarded and the pellet dissolved in $100 \mu \mathrm{L}$ of ultrapure water. RNA removal was performed by addition of $2 \mu \mathrm{L}$ of RNAse $(10 \mathrm{mg} / \mathrm{mL})$ and incubation for 3 hours at $37^{\circ} \mathrm{C}$. The RNA-free extracted DNA was stored at $-20^{\circ} \mathrm{C}$.

Conventional PCR for detection of Lxx was conducted using previously described primers for the amplification of a fragment of the 16S rRNA gene of Lxx (Falloon et al., 2006). In summary, forward primer RSD33 5'-CTGGCACCCTGTGTTGTTTTC-3' and reverse primer RSD297 5'-TTCGGTTCTCATCTCAGCGTC-3' were used to amplify a 265 bp region of the 16Sr RNA gene of the bacteria. In the reactions $10 \mu \mathrm{L}$ of genomic DNA were used, $400 \mathrm{nM}$ of each primer, $200 \mathrm{nM}$ of DNTPs, $1,8 \mathrm{mM}$ of $\mathrm{MgCl}_{2}, 1 \mathrm{X}$ Taq polymerase Buffer $(100 \mathrm{mM}$ TrisHCl pH 8,5 e $500 \mathrm{mM} \mathrm{KCl}$ ), 1,5 units of Taq polymerase (LGCBio, Brazil) and water to a final volume of 25 $\mu \mathrm{L}$. The same amounts of reagents were used in the nestedPCR reaction except that $1 \mu \mathrm{L}$ of the first PCR reaction was used as template and the forward primer RSD60 5'TCAACGCAGAGATTGTCCAG-3' and reverse primer RSD59 5'-CGTCTTGAAGACACAGCGATGAG -3' were used to target a $229 \mathrm{bp}$ internal region of the PCR amplicon. Both reactions were incubated at $95^{\circ} \mathrm{C}$ for 5 minutes, followed by 35 cycles of $95^{\circ} \mathrm{C}$ for $30 \mathrm{sec}, 60^{\circ} \mathrm{C}$ for $30 \mathrm{sec}$ and $72^{\circ} \mathrm{C}$ for $30 \mathrm{sec}$, followed by one final extension step at $72^{\circ} \mathrm{C}$ for $5 \mathrm{~min}$. A $10 \mu \mathrm{L}$ aliquot of the reactions was checked by agarose gel electrophoresis, stained with ethidium bromide and visualized under ultraviolet light. Amplicons were purified using the Illustra GFX PCR DNA and Gel Band Purification kit (GE Healthcare) and cloned with the PCR Cloning Kit (Qiagen) following the protocols of the manufacturers. After cloning the plasmid containing the fragments of interest, they were extracted and purified with aid of Plasmid MiniprepGeneJET kit (Fermentas). After checking the clones with inserts by DNA enzyme digestion, they were submitted to automatic DNA sequencing using a MegaBace1000 DNA Analysis System (GE Healthcare). Sequence identity was checked by similarity search with the BLASTN software (Altschul et al., 1990).

For the qPCR assay, the forward primer Leiftaq $5^{\prime}$ GGGAGCGAACAGGATTAGATAC - 3', reverse primer Leiftaq 5'-CCTTTGAGTTTTAGCCTTGCG-3' and Leiftaq probe 5'-FAM-TAATGCGTTAGCTGCGACACGGABHQ1-3' were used to target a 146 bp region of the $16 \mathrm{~S}$ rRNA gene corresponding to positions 709 to 854 of the GenBank reference sequence DQ232616. The reactions were carried out in a final $25 \mu \mathrm{L}$ volume containing $1 \mathrm{X}$ Master Mix (Roche Real-Time PCR Mix), $200 \mathrm{nM}$ of forward and reverse primers, $100 \mathrm{nM}$ of the probe, and 7.25 $\mathrm{uL}$ of extracted DNA (ap. 0.5-1 $\mu \mathrm{g}$ ). PCR reactions and fluorescence detection were performed using a Stratagene Mx3000P Real-Time PCR System (Stratagene, La Jolla, $\mathrm{CA})$. The thermal cycler program was $95^{\circ} \mathrm{C}$ for 15 minutes, followed by 45 cycles at $95^{\circ} \mathrm{C}$ for 15 seconds and $60^{\circ} \mathrm{C}$ for 1 minute. Samples with a CT (cycle threshold) value between 19 and 34 were considered positive. The sensitivity of the qPCR assay was determined by analyzing 10 -fold serial dilutions of genomic DNA (starting from $10^{7}$ copies). The assay had a detection limit of 10 copies of the Lxx genomic DNA which corresponded to a $\mathrm{Ct}$ of 34.70 .

The bacterial DNA was detected by conventional nested-PCR in stalks and leaves, most commonly in stalk tissue, possibly reflecting the higher titer of bacteria in this tissue. Detection occurred in $23(28.8 \%)$ of stalk samples and in $10(12.5 \%)$ leaf samples. Only in $7(8.8 \%)$ samples bacterial DNA was detected in both tissues. All the samples were retested by the qPCR assay and the results were the same as for the nested-PCR assay, with Ct values varying between 19 and 34. The stalk samples that were positive had a value predominantly in the range of 22 to 34 , while the leaf samples that were positive had a $\mathrm{Ct}$ between 19 and 25. The PCR products from both assays were purified, sequenced and their identity confirmed by homology search with BLASTn (Altschul et al., 1990). Grisham et al. (2007) demonstrated that the efficiency of a Sybr Green real-time PCR assay to detect Lxx DNA was better than conventional PCR assay which had a greater variation of sensitivity. Our results confirm that conventional PCR assays are not sensitive enough to detect Lxx since bacterial DNA was amplified only in the second reaction of the nested-PCR assay. Our qPCR assay uses Taqman probes which is an 
advantage over Sybr Green based assays since it gives higher specificity by the use of three target regions in the gene. Our results showed a $100 \%$ correlation of the qPCR assay with the nested-PCR assay.

Continuous monitoring and management of plant diseases is essential to improve productivity in sugarcane fields. The control of RSD by visualization of symptoms is not reliable since it can be confused with those caused by other biotic or abiotic agents. In order to conduct preventive control, the detection of Lxx needs to be sensitive enough to prevent false negatives from asymptomatic plant material. This may occur due to low bacterial numbers and unequal distribution of the bacteria in plant tissues. Nucleic acid tests based on PCR offer advantages over other methods as it does not recquire the bacteria to be isolated from the plant sample or cultured prior to their detection. Specificity and sensitivity can reach high levels by the use of specific primers and protocols which enable detection of very low bacterial populations. The use of qPCR assays is a further improvement over conventional PCR since it does not require post-PCR processing and can be quantitative. The quantification of the pathogen populations can have a positive impact for epidemiological studies and for evaluation of the efficacy of methodologies used to prevent dissemination of the bacteria. In this regard, the qPCR assay developed here for identification of RSD is a rapid and sensitive nucleic acid test that should improve the diagnosis of the disease. Accelerating the detection of Lxx can support the timely establishment of control measurements to halt the dissemination of the bacteria in sugarcane crops.

\section{ACKNOWLEDGMENTS}

We thank the staff of the Biotechnology Unit, Universidade de Ribeirão Preto - UNAERP, Central Energética Moreno Açúcar e Álcool Ltda and PedraAgroindustrial S/A for general support. Prof. Dr. Luis
A. Camargo (ESALQ-USP) is acknowledged for providing us with the Lxx purified DNA.

\section{REFERENCES}

Altschul SF, Gish W, Miller W, Myers EW, Lipman DJ (1990) Basic local alignment search tool. Journal of Molecular Biology 215:403-410.

Brumbley SM, Petrasovits LA, Hermann SR, Young AJ, Croft BJ (2006) Recent advances in the molecular biology of Leifsonia xyli subsp. xyli, causal organism of ratoon stunting disease. Australasian Plant Pathology 35:681-689.

Davis MJ, Gillaspie AG, Harris RW, Lawson RH (1980) Ratoon stunting disease of sugarcane: Isolation of the causal bacterium. Science 210:1365-1367.

FAO - Food and Agriculture Organization of the United Nations (2010) Faostats. Available at: faostat.fao.org/site/339/default.aspx. Accessed on June 21, 2012.

Falloon T, Henry E, Davis MJ, Fernandez E, Girard JC, Rott P, Daugrois JH (2006) First report of Leifsonia xyli subsp. xyli, causal agent of ratoon stunting of sugarcane, in Jamaica. Plant Disease 90:245-245.

Gillaspie AG, Davis MT, Harris RW, Lawson RH (1981) Isolation and pathogenicity of the ratoon stunting disease bacterium. International Sugar Journal 83:324-326.

Grisham MP, Pan YB, Richard EP (2007) Early detection of Leifsonia xyli subsp. xyli in sugarcane leaves by real-time polymerase chain reaction. Plant Disease 91:430-434.

Richards E, Reichardt M, Rogers S (2001) Preparation of genomic DNA from plant tissue. In: Ausubel FM, Brent R, Kingston RE, Moore DD, Seidman JG, Smith JA, Struhl K (Eds.) Current Protocols in Molecular Biology. New York NY, USA. John Wiley $\&$ Sons.

Tokeshi H (1997) Doenças da cana-de-açúcar. In: Kimati H, Amorim L, Rezende JAM, Bergamin Filho A, Camargo LEA(Eds.) Manual de Fitopatologia. vol 2. Doenças das plantas cultivadas. 3rd Ed. São Paulo SP. Agronômica Ceres. pp. 207-225. 